overblik. Sådan et, og et yderst kundskabsrigt et, er nu foræret til interesserede udenlandske læsere. Det står dem herefter frit at kravle rundt på, hvad der er meget mere end en eventyrdigter.

Anmeldt af Dan Ringgaard

\title{
Verdenslitteratur i Frankrig
}

Mads Anders Baggesgaard, Nye franske verdener. Aarhus Universitetsforlag, Verdenslitteratur 5, 2016, 292 sider.

Globaliseringsbegrebets indtog i forskningsmiljøerne har tilføjet litteraturhistorien en ny dimension, som i de komparative litteraturvidenskaber særligt har kunnet aflæses i udviklingen af feltet verdenslitteratur. Det er fra dette ståsted, Mads Anders Baggesgaard i femte bind i Aarhus Universitetsforlags Verdenslitteratur-serie indleder sin afsøgning af globaliseringens aftryk og udtryk i nyere fransk litteratur. Udgangspunktet er en konstatering af, at Frankrig er et land i dyb krise. Stillet over for globaliseringens forandringer og det engelske sprogs dominans leder forfattere og intellektuelle i den tidligere politiske og kulturelle stormagt efter nye måder at forstå sig selv i verden på, og bogens projekt er at undersøge, hvordan dette reflekteres i litteraturen.

De to første kapitler forankrer problemstillingen i henholdsvis det empiriske og det teoretiske felt. Frédéric Beigbeders Un roman français fra 2009 bruges til at anskueliggøre den indledende diagnose om et kriseramt folk, der har tabt to krige og et kolonirige uden at bearbejde det, og som sidenhen har solgt deres sjæl til den globaliserede kapitalisme, hvor kulturen kun gives to overlevelsesmuligheder: enten som kulturarv eller som markedsprodukt.

Globalisering ses som en proces, der "skaber inter- og transnationale netværk og forbindelser på en række forskellige niveauer" (s. 30), og netop forskelle i niveau og perspektiv er en central udfordring for en litteraturhistorie, der har som mål at forbinde værkets mindste dele med dets globale indlejring. Baggesgaard finder inspiration hos en række af de seneste ti-tyve års markante litteraturhistorikere som f.eks. Emily Apter, Pascale Casanova, David Damrosch, Franco Moretti og Gayatri C. Spivak, men vedkender sig også indflydelse fra filosofien og New Historicism, der retter opmærksomheden mod andre diskurser end de rent litterære.

På den baggrund formuleres et ambitiøst projekt, der ved at forbinde en række niveauer og dobbeltheder - dansk/fransk, national/global, tekst/kontekst, litterære/ metalitterære diskurser, fransk/frankofon - sigter mod at give et bud på, hvordan der kan skrives litteraturhistorie i dag. Det lykkes over lange stræk i bogen, der i øvrigt præsenteres smukt og indbydende med et detaljeret noteapparat, en fyldig biografi og som prikken over i'et en række fine og velvalgte illustrationer af kupler, glober, sfærer og himmelrum.

Bogen falder i to hoveddele, hvoraf den første, "De franske og verden”, opererer med stor distance til de litterære værker. Her trækkes med fint overblik linjerne i den 
franske kulturpolitik fra Charles de Gaulle til den siddende præsident, og der ses nærmere på receptionen af den fransk-amerikanske forfatter Jonathan Littells prisbelønnede roman Les Bienveillantes fra 2006. Romanens verdensomspændende succes er af franske litteraturkritikere blevet læst som bevis på, at den franske tradition kan revitaliseres med impulser udefra, og Baggesgaard argumenterer overbevisende for, at kritikernes fortolkning bærer aftrykket fra globaliseringens pres på Frankrig.

Den anden hoveddel, "Litterære verdener", ophæver distancen til værket med en række nærlæsninger af tekster af Georges Perec, François Bon, Michel Houellebecq og Pierre Alféri. Der peges i analyserne på forskellige former for realisme - globaliseringsrealisme, medierealisme, autofiktion og "global realisme" - inden det bl.a. med inddragelse af den algierske forfatter Boualem Sansals roman 2084 konkluderes, at det i dag er forholdet mellem "det historiske og en radikaliseret rumlighed " (s. 209), der reflekteres i de litterære værker. Hermed bliver litteraturen "postglobal", hvilket betyder, at det globale ikke skal ses som et tillæg til det lokale, men som noget, der indskriver sig overalt: i dagligdagen, i økonomien og i sproget (s. 210).

Baggesgaard er en meget grundig og opmærksom læser og særdeles velbevandret i nyere litteratur- og kulturteori, hvilket til fulde demonstreres i de enkelte analyser, der gribes an fra forskellige vinkler og på skiftende skala. Bons socialrealistiske $D a$ ewoo læses for eksempel i lyset af den franske litterære tradition i form af Zolas Germinal, mens analysen af Houellebecqs La possibilité d'une île udfolder sig på et bagtæppe af værker hentet fra en bredere litterær horisont. Det er fine eksempler på, hvordan de litterære værker er i dialog med litteratur fra andre tider og rum. Et par længere ekskurser om Deleuzes filmteori i flere af kapitlerne synes derimod ikke at bidrage til at besvare spørgsmålet om, hvordan man kan skrive litteraturhistorie på verdenslitterære præmisser.

Man kan derfor af og til få en fornemmelse af en manglende indre sammenhæng, hvad der eventuelt kan forklares med - som en forfatternote sidst i bogen gør opmærksom på - at en del af kapitlerne tidligere har været udgivet som artikler i forskellige sammenhænge. Måske af den grund synes en række af fremstillingens væsentlige begreber at betyde noget forskelligt i de forskellige kapitler. Det er naturligvis en væsentlig pointe i forhold til det overordnede projekts fokus på forskelle i niveau og perspektiv, men når analyserne skal give anledning til at diskutere, hvordan litteraturhistorie kan og bør skrives i en globaliseret verden (s. 18), ville det være relevant at afklare, hvad kontekst betyder - om det er et globalt marked for litteratur, fabrikslukninger eller den franske litterære tradition - ligesom det ikke er helt klart, om det er analytikeren eller teksten, der afgør, hvad der er relevant kontekst i hvert enkelt tilfælde, og om verden er den, fiktionen skaber, eller den, vi lever i.

Hvad "fransk" omfatter, bestemmes klart af Baggesgaard: "Bogens emne er altså globaliseringen, som den opleves og reflekteres på det franske fastland - inden for den franske heksagon - med udgangspunkt i den franske tradition" og "[d]en franske litteratur skrevet uden for Frankrig er fravalgt" (s. 24-25. Mine kursiveringer). Denne ramme sprænges dog her og der, navnlig i bogens sidste kapitel om algierske Sansal.

Undervejs kan man således sætte spørgsmålstegn ved visse til- og fravalg. Mens på den ene side den fransk-amerikanske og meget kosmopolitiske Littells roman fal- 
der ind under bogens udvælgelseskriterier, er andre prisbelønnede romaner skrevet af "bindestregs-franskmænd" som fransk-canadiske Nancy Huston og fransk-congolesiske Alain Mabanckou ikke inddraget. Det kan skyldes, at de ses som "frankofone" snarere end "franske", og Baggesgaard har da også forklaret, at der ikke vil blive levnet meget plads til "beskrivelsen af frankofon litteratur fra andre steder i verden [...] ja, end ikke til beskrivelsen af eksil- og migrantlitteratur undfanget inden for landets grænser", og at kun den "institutionelt franske" (s. 24) litteratur vil blive behandlet. Spørgsmålet er imidlertid, om Mabanckous romaner, som stort set uden undtagelse er udgivet på franske forlag, ikke er lige så "institutionelt franske" som Littells.

Nationen og nationalsproget som ramme om litteraturen forsvinder ikke, skriver Baggesgaard, "blot fordi varer, kommunikation og mennesker begynder at cirkulere i bredere internationale cirkler [...] . Nationallitteraturerne opsamler på godt og ondt det intime liv som kollektiv erfaring og forbliver som sådan referencerammen for den litterære produktion" (s. 19). Det kan dog næppe bestrides, at denne ramme ændrer sig i takt med, at migrantforfattere og 3.- og 4.-generations-franskmænd føjer deres fortællinger til repertoiret af kollektive erfaringer. Forfattere med blandet oprindelse er, som en gruppe yngre franske forfattere med afrikansk og nordafrikansk baggrund skrev i forordet til antologien Qui fait la France fra 2008, børn af et mangfoldigt Frankrig, og mange af dem har søgt efter og skrevet om måder at være fransk i Frankrig og i verden på.

Bogens indre spændinger illustrerer måske bedre end noget teoretisk begreb, hvor komplekst et foretagende det er at indfange globaliseringens konsekvenser ikke bare for litteraturen, men også for litteraturhistoriens metoder og kategorier. Hvortil de(n) franske verden(er) går, er derfor efter endt læsning stadig et åbent spørgsmål. Men det ændrer ikke ved, at Baggesgaard med sin bog har leveret et både inspirerende og kvalificeret udgangspunkt for den videre diskussion.

Anmeldt af Lisbeth Verstraete-Hansen 